University of New Orleans

ScholarWorks@UNO

Winter 1991

\title{
Environmental Policy in the EC: Neo-Functionalist Sovereignty Transfer or Neo-Realist Gate-Keeping?
}

\author{
Michael G. Huelshoff \\ University of New Orleans, MHuelsho@uno.edu \\ Thomas Pfeiffer
}

Follow this and additional works at: https://scholarworks.uno.edu/ps_facpubs

Part of the Political Science Commons

\section{Recommended Citation}

Huelshoff, Michael G. and Thomas Pfeiffer. 1991. "Environmental Policy in the EC: Neo-Functionalist Sovereignty Transfer or Neo-Realist Gate-Keeping?" International Journal. 47:136-158.

This Article is brought to you for free and open access by the Department of Political Science at ScholarWorks@UNO. It has been accepted for inclusion in Political Science Faculty Publications by an authorized administrator of ScholarWorks@UNO.For more information, please contact scholarworks@uno.edu. 


\section{Environmental policy in the EC: neo-functionalist sovereignty transfer or neo-realist gate-keeping?}

The European Community (EC) stands at an important crossroads. Despite delays and uneven implementation, the $\mathrm{EC}$ is poised to move towards completing its Single Market Programme, and monetary union is to be realized by the end of the decade. Additionally, for the first time in some time, members are seriously discussing revisions to the Treaty of Rome that would strengthen political integration and set in motion institutional reform, and initial steps to do so were taken at the Maastricht summit in December 1991. Yet the EC was initially designed to further economic integration among its members. Original academic conceptions perceived the $\mathrm{EC}$ as a functional institution, designed to enhance economic co-operation (in order to tie together many of the combatants of World War II so closely that in the future wars would be unlikely if not impossible) without the need for closer institutional association.'

\footnotetext{
Michael c. hueishoff is Assistant Professor of Political Science, University of Oregon, Eugene. Thomas pFE1FFer completed his master's degree at the University of Oregon.

An earlier version of this paper was presented at the $199^{\circ}$ meeting of the Western Political Science Association. The authors would like to thank Richard Buxbaum, Arthur M. Hanhardt Jr, and the reviewers of the International Joumal for their comments.
}

I D. Mitrany, A Working Peace System (London: Royal Institute of International Affairs and Broadwater Press 1944); D. Mitrany, 'The prospect of integration: federal or functional?' in A.J.R. Groom, and P. Taylor, eds, Functionalism (London: University of London Press 1975); P. Taylor, "The functionalist approach to the problem of international order,' Political Studies 16(1968), 393-409; J.P. Sewell, Functionalism and World Politics (Princeton NJ: Princeton University Press 1966). 
Events quickly overtook such (in retrospect) naive academic musings, and notions of integration that included expressly political processes, working together with economic integration, captured attention. ${ }^{2}$ These so-called neo-functionalist theories fared as poorly as their functionalist predecessors, leading Ernst Haas to proclaim the obsolescence of regional integration theory - and, by implication, regional integration - during the economic instability of the 1970 s. $^{3}$ All this academic pessimism has been overturned by the 1992 programme and the apparent commitment of key EC member-states to expand regional integration.

The extent to which integration in Europe is leading to the transfer of sovereignty from member-states to Community institutions is a central question engendered by this renewed drive towards greater regional integration in the $\mathrm{ec}$. To explore the issue of sovereignty transfer, this essay examines the development of environmental policy in the Ec. The increase in environmental awareness among the general public has pushed the EC to pursue environmental goals more aggressively, and the Single European Act (SEA) proposes a balance between market and environment. But as the act has been implemented to date environmental policies have taken a back seat to economic integration. An 'environmentally friendly' Europe is unlikely to

2 See E.B. Haas, 'International integration: the European and the universal process,' International Organization 15 (summer 1961), 366-92, and Beyond the NationState (Stanford CA: Stanford University Press 1964); L.N. Lindberg, The Political Dynamics of European Economic Integration (Stanford CA: Stanford University Press (963), and 'The European Community as a political system,' Journal of Common Markel Studies 5 (June 1967), 344-87; L. Lindberg and S. Scheingold, Europe's Would-Be Polity (Englewood Cliffs NJ: Prentice-Hall 1970); J. Caporaso, 'Encapsulated integrative patterns vs. spillover: the cases of agricultural and transport integration in the European Economic Community,' International Studies Quarterly 14(December 1970), 361-94; J.S. Nye, Peace in Parts: Integration and Conflict in Regional Organizations (Boston: Little Brown 1971); B.M. Russett, 'Transactions, community, and international political integration,' Joumal of Common Market Studies 9(March 1971), 224-45; P. Schmitter 'Three neo-functional hypotheses about international integration,' Intermational Organization 23 (winter 1969), $161-6$.

3 The Obsolescence of Regional Integration Theory, Research Series 25 (Berkeley: Institute of International Studies, University of California, 1975). 
emerge in 1992 or thereafter until national publics make greater demands on their governments for more protection of the environment and there is a greater willingness on the part of the European Commission to balance market and environmental goals.

Yet the politics of Ec environmental policy is not exclusively a policy question. There are valuable lessons for theory in postsEA environmental policy. The politics of $\mathrm{EC}$ environmental policy demonstrates the weaknesses of re-worked theories of regional integration which emphasize neo-functionalist spillover and the transfer of sovereignty to $\mathrm{EC}$ institutions. While the balance between market and environment written into the Single European Act makes environmental policy seem a good candidate for spillover and sovereignty transfer, to date there has been little spillover from the market-oriented elements of the SEA into environmental policy. Rather, national sovereignty remains a powerful force in EC politics, despite the 'Europhoria' of recent years and the renewed drive towards greater political integration in the $\mathrm{EC}$.

This essay first reviews recent attempts to revive and reformulate integration theory. In particular, attention is focused on the growing debate between those scholars who argue for a return to neo-functionalist concepts and those who note the continuing importance of national sovereignty and the gatekeeping role of national governments. The second section describes the policy-making context in the EC as it pertains to environmental questions. Pro-growth interest groups at the European level have found a sympathetic ear in the Commission, at the expense of pro-environment groups. Yet the major actors in the Ec remain the nation-states, underscoring the importance of the European Council and the Council of Ministers in determining the pace and direction of European environmental policy. The European Parliament, the main institution in which environmental concerns are voiced, is structurally hampered from taking a more forceful position and cannot itself balance market and environment. The final section of the article demonstrates the effects of this distribution of political power in two 
areas of environmental concern - waste management and air pollution - and explores the impact of the structural factors discussed on these policy areas. The implications for integration theory are examined in the conclusions.

\section{AND INTEGRATION THEORY}

The replacement of 'Europessimism' with 'Europhoria' has generated a debate in academia. The dynamism of the $199^{2}$ project and its related efforts to expand monetary and political cooperation in Europe have led scholars to reconsider the wisdom of Haas's postmortem on regional integration. Smith and Ray decry the demise of integration theory in United States political science, arguing that even in the times when it seemed the $\mathrm{EC}$ was stagnant, there was evidence of continued integration in Europe, but they offer few specific suggestions as to what theoretical tools remain useful. In recent studies, Taylor and Tranholm-Mikkelsen both find evidence of spillover, a concept central to neo-functionalist theory. Sandholtz and Zysman focus upon 'elite bargains formed in response to changes in the international structure and in the domestic political context.' They believe these bargains involve interlocked trade-offs among nations, resulting in the transfer of decision-making authority to the Commission. While careful to evaluate neo-functionalism and to note the difficulty of predicting continued co-operation, Sandholtz and Zysman do share one belief with those arguing for a reconsideration of neo-functionalism. They hold out the possibility - however tentatively - of the development of a European single actor in international politics, implying a transfer of sovereignty from member-states to the Ec. ${ }^{4}$

4 D.L. Smith and J.L. Ray, 'European integration: gloomy theory versus rosy reality,' paper presented at the annual meeting of the American Political Science Association, Atlanta, Georgia, 31 August-3 September 1989; P. Taylor, 'The new dynamics of E.c: integration in the $1980 \mathrm{~s}$,' in J. Lodge, ed, The European Community and the Challenge of the Future (New York: St Martin's Press 1989), 3-25; J. Tranholm-Mikkelsen, 'Neo-functionalism: obstinate or obsolete? A reappraisal in the light of the new dynamism of the ec,' Millennium 2o(spring 1991), 1-222; W. Sandholtz and J. Zysman, '1 992: recasting the European bargain,' World Politics 42(October 1989), 95-1.8. 
Other scholars are more sceptical about the processes at work in Europe and about their likely outcomes. In a study of the formulation of the Single European Act, Moravcsik finds that states were willing to pass little sovereignty to the Commission, even if agreeing to co-ordinate policy among themselves. He argues that traditional concepts of power and national interest best describe developments in Europe. Keohane and Hoffmann are also somewhat doubtful about the prospects for longrange integration and sovereignty transfer in Europe. Busch argues that there is an inherent contradiction between the nation-state and integration, which nation-states have won in the past and will continue to win in the future. ${ }^{5}$ These perspectives are largely consistent with intergovernmentalism, which is based in neo-realist international relations theory. ${ }^{6}$ From this neo-realist perspective, states will maintain their gate-keeper role in $\mathrm{EC}$ politics, limiting the transfer of sovereignty.

This debate suggests two rival hypotheses. If spillover and/ or interlocking trade-offs are common in the development of European environmental policy, then sovereignty is being transferred to the Ec. If states continue to be the focus of decisionmaking, then the EC might better be characterized as another organization within which states interact, a 'concordance system' in Puchala's terms. ${ }^{7}$

\footnotetext{
5 A. Moravcsik, 'Negotiating the Single European Act: national interests and conventional statecraft in the European Community,' International Organization 45 (winter 1991), 651-88; R.O. Keohane and S. Hoffmann, 'Institutional change in Europe in the 1980s,' in Keohane and Hoffmann, eds, The New European Community: Decisionmaking and Institutional Change (Boulder co: Westview 1991), $1-4$ (' K. Busch, 'The conflict between nation-states and economic integration in the European Community,' in B. Crawford and P. Schulze, eds, The New Europe Asserts Itself: A Changing Role in International Relations (Berkeley: University of California Press 1990), 153-78.

6 Tranholm-Mikkelsen, 'Neo-functionalism: obstinate or obsolete?' 8. For representative intergovernmentalists, see $S$. Hoffmann, 'Obstinate or obsolete? The fate of the nation-state and the case of Western Europe,' Daedalus 95(1966), 862915, and P. Taylor, The Limits of European Inlegration (London: Croom Helm $1983)$.

7 D. Puchala, 'Of blind men, elephants and international integration,' Journal of Common Market Studies Io(March 1972), 267-84.
} 
Why environmental policy? Environmental issues were explicitly included in the Rome treaties in 1987 with the ratification of the Single European Act, and there has been rapid growth in public awareness about the environment during the past decade. The relative success of environmental political parties in the most recent election for the European Parliament, including strong showings in France and the United Kingdom, underscores the growing importance of environmental politics in the Ec. It is this recent addition of environmental issues to the Rome treaties and the rapid growth in political awareness of environmental problems which make these issues a strong candidate for explorations of sovereignty transfer in the Ec.

THE POLITICS OF

ENVIRONMENTAL POLICY MAKING IN THE EC

The original Treaty of Rome included no provisions related to the environment. In the late 195 os, few environmental lobbies were pressing for environmental protection and although wartime damage had largely been repaired, European states were still far behind the United States in most major economic categories. Article 1 oo of the treaty specified that the Commission was to work to harmonize members' policies to realize the internal market. This article is broad enough to be interpreted both as a means to develop a European environmental policy and as a means to weaken national environmental laws that distort trade. The remaining articles of the treaty with implications for the environment included article 2, which sets the broad goal of 'balanced development,' and article 36 , which allows members to ban or restrict trade to protect public health, animals, and plants. However, the treaty included very little that can be interpreted as pertaining to the environment - and nothing that directly confronts the issue.

Environmental issues did not reach the bargaining table until $197^{2}$ when the Council of Ministers voted to establish an Environmental Action Programme (EAP), but environmental policy developed only slowly thereafter. Not only was the timing 
poor-coming shortly before the $1973-4$ oil crisis and subsequent recession - but also the Ec was running out of political steam. Weakened by the French boycott in 1965 , the Commission was unable to maintain cohesion among its members after the Nixon shocks of 197 I effectively ended the fixed exchange rate system. The subsequent oil crisis set off inflationary pressures that tested the political will of the European states. Indeed, Haas's observation that integration was 'obsolescent' in 1975 seemed all too true. While over 100 directives pertaining to the environment were adopted by the Ec between 1973 and 1988, unanimity voting requirements and poor implementation ensured that environmental standards remained low and policy unco-ordinated.

One result of these lowest-common-denominator policy outcomes was that individual states were allowed to set environmental standards higher than those in the $\mathrm{EC}$, as long as these higher standards were not judged to be designed to restrict trade. Yet the Commission was unable to police this situation. Some members, such as the Federal Republic of Germany, Denmark, and the Netherlands faced strong domestic pressures to implement even higher standards than those possible in the Ec. Other governments, such as the United Kingdom, had little interest in environmental policy, because short river drainage systems, weather patterns, and the ease of ocean dumping of waste materials obscured environmental problems and limited public expressions of concern about the environment in that country. Until recently, little political pressure was brought to bear upon the government in the United Kingdom to protect the environment.

Even when lowest-common-denominator policies did exist in the Ec, enforcement of the policies was slow. The question of subsidiarity between the $\mathrm{EC}$ and its member-governments raises the issue of competence in environmental policy. ${ }^{8}$ There is con-

$8 \mathrm{~J}$. Lodge, 'Environment: towards a clean blue-green Ec?' in Lodge, ed, The Community and the Challenge of the Future, 323 . 
troversy over whether Community environmental policy should be implemented at the national or the Ec level. In addition, the Commission's use of directives rather than regulations directives allow states more leeway in implementing EC policies limits the ability of individuals to bring cases to the European Court of Justice. ${ }^{9}$ Finally, the structural problems that the Court faces in all areas, including the large docket of complaints before it, restricts timely adjudication of complaints on environmental policy. While the Court has begun - with the Cassis de Dijon and other rulings - to take a larger role in Ec politics, " including the enforcement of environmental standards, the level of noncompliance remains high. Overall, compliance with the Ec's environmental policy can be judged a failure.

The Single European Act of 1987 appeared to be a watershed in European environmental policy. Partly at the insistence of the European Parliament, and in recognition of the growing environmental lobbies in national capitals, articles $130 R-T$ of Title 7 of the act addressed environmental issues. For the first time expressly within the treaty itself the Commission was made responsible for integrating environmental concerns into $\mathrm{EC}$ policy. Article $130 \mathrm{or}$ specified the goals of Ec environmental policy, including the preservation and the improvement of the quality of the environment, the protection of human health, and the encouragement of the prudent and rational utilization of natural resources. The policy principles to be used in meeting these

9 D. Vandenmeersch, 'The Single European Act and the environmental policy of the European Economic Community,' European Law Review $12(1987)$, 407-29.

$10 \mathrm{G}$. Slynn, 'The concept of the free movement of goods and the reservation for national action under art. 36 EEC Treaty,' in J. Schwarze, ed, Discretionary Powers of the Member States in the Field of Economic Policies and Their Limits Under the EEC Treaty (Baden-Baden: Nomos 1988), 17-24. In the Cassis de Dijon case the Court ruled that Germany could not exclude French cassis from its market because it had a different alcohol content than that proscribed for cassis in German law. In short, like products must be treated the same, even if there are slight differences in content. The same interpretation has been applied to margarine, beer, and sausages, effectively striking down narrow national definitions of products which distorted trade. In these rulings, the Court signalled to member-states that they must obey both the letter and the intent of Community legislation. 
goals were consistent with those developed under the EAP: preventive action, the polluter pays, rectification at the source of environmental damage, and the inclusion of environmental concerns in the other activities of the Ec. Article 130 specified the conditions under which qualified majority voting could be applied in making decisions about environmental policy, and article 1 зот allowed members to maintain higher levels of environmental protection than agreed to in the $\mathrm{EC}$ as long as those standards were not designed to distort trade.

Although the SEA strengthened the powers of the Commission to pursue a European environmental policy, there remained political difficulties in realizing this power. These difficulties stemmed from a potential contradiction in goals. Title 7 specifies an important environmental constraint upon economic activity, yet the main thrust of the $199^{2}$ programme is to free markets and stimulate economic activity. This increased economic activity would presumably increase levels of pollution. The Single European Act thus mandates objectively inconsistent goals.

The Commission and some member-governments - notably Germany - argue that growth and environmental goals are not incompatible. " They suggest that growth is possible using the cleanest available technologies. This is consistent with longstanding environmental policies in the Federal Republic and, incidentally, places German business in a strong position to export anti-pollution technology. Other member-states, including the United Kingdom, set overall levels of pollution to be allowed in a given area, irrespective of the cleanliness of the technologies being used. This regulatory approach is more likely to result in higher levels of pollution and leaves the United Kingdom in a less competitive position in the export of environmental protection technologies after 1992. Therefore, harmonization of environmental policy in the $\mathrm{EC}$ is hampered by wide 
gaps in regulatory approaches across members, and the political difficulties in finding domestic support for compromises. ${ }^{12}$ Adopting the German regulatory style would place significant burdens on companies operating in countries using site pollution regulations and enhance German dominance in capital goods markets. Yet adoption of the site pollution approach or some compromise between the two will face strong opposition from highly organized environmental groups in Germany, the Netherlands, and Denmark - possibly in an unlikely coalition with exporters of clean technology. The basis for a political compromise on regulatory form is weak, and national differences in pollution control are likely to continue for some time.

Moreover, development needs constrain concern for the environment in Spain, Portugal, southern Italy, Greece, and Ireland. The most significant problems facing these economies include unemployment and low levels of growth, issues which attract a broader range of public interest than does the environment. It is largely the tourism industries in these countries which support environmentally conscious development policies. These countries, and occasionally the French, ${ }^{3}$ regularly oppose a greater balance between the market and the environment in the EC and often demand exemptions and extensions in meeting European environmental policies.

The ambiguity in the SEA and the opposition of some member-states to higher environmental standards have led to market goals being put before environmental goals in the Ec. The Directorate General for Environment, Consumer Protection, and Nuclear Safety (DG XI) must compete within the Commission

12 Lodge, 'Environment: towards a clean blue-green ec?' 324 .

13 French opposition to the imposition of stricter European environmental standards could until recently be explained mostly by French needs to remain competitive vis-à-vis the Germans, but the growth of environmental lobbies and political parties may awaken political concern there as well. For a recent treatment of French environmental politics, see G. Blume, 'Auf der Suche nach einer umweltpolitischen Moral,' in M. Franken and W. Ohler, eds, Natürlich Europa (Köln: Kölner Volksblatt Verlag 1989), 21-30. 
with the Directorates General for Internal Market and Industrial Affairs, for Energy, and for Agriculture for resources and influence over environmental policy. It is also clear that for the Commission's president, Jacques Delors, market comes before environment. Although Mr Delors supported the establishment of a Community Environment Office, ${ }^{14}$ it has few powers except as an information service. He suppressed a report prepared by DG XI which was critical of the environmental implications of the 1992 programme. ${ }^{15} \mathrm{Mr}$ Delors clearly understands the pressing priority of environmental protection and feels the growing influence of environmental lobbies and political parties in the member-states, but he is unwilling to risk slowing down or sacrificing the 1992 programme in order to balance market and environmental goals. Therefore he refused to allow the DG xi's report to be issued formally, although it was leaked to the environmental community. The expansion of EC powers into the environmental field would be desirable for the evolution of the Commission, yet the Commission has clearly placed market before environment.

The major European interest groups concerned with environmental issues fall on one or the other side of this marketenvironment controversy. The Union of Industrial and Employers' Confederations of Europe (UNICE), the main lobbying group in Brussels for business, supports the market-first orientation of the Commission. This organization argues that 'a sound economy is a precondition for effective environmental protection since it provides the means for paying the costs of clean operations. ${ }^{\prime} 6$ $\mathrm{UN} \mathrm{ICE}_{\mathrm{Ndds}}$ that investment incentives are preferable to legislative constraints in the pursuit of environmental policy goals, that there is a need for increased self-regulation and public support

14 'EG-Umweltpolitik wird priorität: Präsident Jacques Delors will Europäisches Umweltamt,' EG Nachrichten, no 8, 25 April $1989,2$.

15 Authors' interviews in Brussels, 25 January $199^{\circ}$.

16 'European industry and the environment - the fundamental principles of environmental policy,' UNIC: doc inc:o 89033/rev., 10 October 1989. 
for research and development, worker retraining, and so on, and that the polluter pays principle is preferable to the collective burden principle. These positions are all broadly consistent with a market-first perspective on the environment. The European Trade Union Confederation (ETUC), the main lobbyist for the labour movement in Europe, named 'environment and employment' as one of its three main goals for the next three years at its Milan Conference in 1985 . Yet environmental questions were largely ignored at its follow-on conference in Stockholm in May 1988. ${ }^{17}$ The confederation pressed for the integration of environmental issues into the general debate concerning the future of industrial society and for information programmes to show that environmental protection can create jobs. Nevertheless, the final report of the Stockholm conference devoted only a few pages to environmental questions. It would seem that ETuC is largely constrained by its members, many of whom fear that stronger environmental standards could cost jobs.

Environmental interest groups in the $\mathrm{EC}$ are represented in Brussels by the European Environmental Bureau (EEB) and the Institute for European Environmental Policy (I EEP). ${ }^{18}$ The EEB represents national environmental groups in Brussels and has close ties with DG XI in the Commission. It highlights the negative effects of the 1992 programme for the environment, but finds the Commission largely deaf to its pleas. It has therefore directed its efforts towards strengthening the pressure upon national governments to address environmental issues by helping to organize environmental groups in the member-states and by sensitizing the general public to environmental concerns. The E E B recognizes that in environmental affairs power still resides in the national capitals. The $1 \mathrm{EEP}$, in contrast, argues that the 1992 programme will lead to higher levels of pollution only a

${ }_{7}$ European Trade Union Confederation, Report on Activities $85 / 87$, Stockholm, 913 May 1988.

18 'The information in this paragraph is drawn from the authors' interviews in Brussels and Bonn, January and February $199^{\circ}$. 
little earlier than would have been the case without the programme. While it is concerned with environmental protection, the IEEP emphasizes the differing impacts of the problems on EC member-states and the varying approaches to their solution which exist among those members. ${ }^{19}$

Behind these different views of the potential impact of the 1992 programme on the environment lie two radically different perspectives. On the one side, the representatives of business and labour, including UNICE and to some extent ETUC, tend to emphasize the wealth to be generated by the 1992 programme and to argue that this wealth can then be applied to clean up the environment. They are inclined to gloss over the differences in approach to environmental questions among member-states and the difficulties that these differences are likely to generate in developing effective European environmental standards and policies. On the other side is the EEB, which stresses the environmental damage to be expected as a result of the 1992 programme. The IEEP, while decrying the damage likely to occur as a result of the programme, notes that this is simply an acceleration of current processes and that national differences in approach to environmental policy heighten the difficulties in agreeing on Europe-wide measures to protect the environment. Capital, and to some extent labour, see the 1992 programme leading to investment in protecting the environment as a result of increased growth, whereas the environmental groups emphasize the environmental damage to be caused by the programme. These groups also note the present difficulties in reaching agreement among the members of the Ec, suggesting that even with increased prớfits after 1992, differing sensitivities and approaches to environmental concerns among Ec members limit the likelihood that increased profits will in fact be spent on meeting European environmental standards.

19 See, for example, the remarks of Ernst Ulrich von Weizsäcker, director of the I EEP, in Europäische Liga für Wirtschaftliche Zusammenarbeit, Die Europäische Dimension im Umweltschulz (Köln: Industrie-Förderung 1988). 
In this political climate, the Commission is relatively free to pursue market first, environment second policies. While reaching Community-wide environmental standards is somewhat easier with qualified majority voting on some issues, the huge differences among members require low- (but perhaps not least-) common-denominator types of resolutions. The European Parliament, constrained to play a primarily advisory role, can do little to change the priorities of the Commission despite its large pro-environment bloc of members.

European environmental policy, then, operates in a highly constrained political milieu. Both the Commission and business lobbyists clearly place completion of the internal market before protection of the environment, and the environmental lobbyists are unable to do much to change this stance. Achieving more balance between market and environment, as called for in the Single European Act, would require more pressure from member-governments to pursue this objective, and this requires, in turn, more effective environmental lobbies in each of the member-states. The theoretical implication of these observations is an emphasis on the primary role of states in decision-making. This constellation of political forces offers little hope for development of a European environmental policy, a judgment that raises the question of sovereignty transfer. To determine if, despite these political and institutional constraints, the EC has been able to acquire sovereignty from its members in the area of environmental policy, we will explore the Ec's handling of two environmental issues: waste management and air pollution.

THE EC AND WASTE MANAGEMENT

One of the main goals of the SEA process is the elimination of border controls. The 1992 programme envisions a Europe without borders, where goods, services, money, and people may move freely without the time-consuming checks and delays now experienced at most border crossings. Such an open Europe generates the potential, as well, of states with low environmental 
standards becoming dumping grounds for wastes, including hazardous materials. Without the border checks, companies may be tempted to ship their wastes about Europe until a likely dump site is found in a country where government officials either do not know or do not care what is dumped where. This so-called waste tourism has in the past generated strong public concern, beginning in 1976 when an explosion at a chemicals plant covered the Italian town of Seveso with large amounts of cancercausing dioxins. The control of waste shipments is thus one of the key issues in any European environmental policy.

The EC has tried to implement waste management policies since $1975 .{ }^{20}$ Its first efforts were overly broad and were directed primarily at Community-level disposal of toxic and non-biodegradable materials. The Action Programme of 1977 significantly expanded the scope of Commission activities in the area of waste management to include the reduction of the quantity of nonrecyclable waste, increased recycling efforts, and the disposal of non-recyclable wastes. However, there were significant enforcement problems, and a number of waste disposal scandals heightened the sense that the EC was not able to force compliance upon its members. One partial success was the emphasis during the 1980 upon clean technologies, with the Commission supporting pilot projects demonstrating the feasibility of new technologies which minimized environmental degradation.

One of the Ec's major failures was over the discharge of wastes into the sea. Several governments, notably that of the United Kingdom, have effectively blocked efforts to regulate dumping at sea. While the highly publicized deaths of large numbers of seâls in the North Sea galvanized public attention to force an agreement limiting such dumping in 1988 , the British have since applied for temporary extensions on its implementation, and there is evidence that the dumping continues. In this case, initiatives for new policy came solely from member-govern-

20 For a detailed description of EC waste policy, see S.P. Johnson and G. Corcelle, The Environnental Policy of the European Communities (London: Graham and Trotman 1989), $15^{8-86}$. This analysis draws in part upon their work. 
ments, yet implementation has been blocked by member-governments.

Implementation of the Seveso directive has been equally hampered by national governments. Passed in 1982 , this directive lays down regulations concerning the handling and storage of hazardous materials. In the first five years after its passage, only a handful of member-governments implemented the directive, and full implementation remains elusive. ${ }^{21}$ The foot-dragging evident in this case - despite the Seveso scandal - is indicative of the implementation problems already experienced in the run-up to $199^{2}$ and demonstrates that member-states retain considerable control over environmental policy.

After a warehouse full of inadequately stored dioxin was found in northern France, the Ec adopted regulations in 1984 requiring members to inform each other of the shipment of hazardous wastes to prevent waste tourism. It is unclear to what extent these requirements are being observed. Differences in storage and dumping standards, despite the Seveso directive, raise the possibility that some member-states will become, willingly or not, the dumping ground for others. There is some evidence, for example, that German firms are holding back on investments in new facilities to process hazardous wastes until after 1992, in the hope that less expensive means - meaning dumps in other states with lower environmental standards - can be found to dispose of the material. ${ }^{22}$

One reason why waste tourism is likely to increase after 1992 arises from the position taken by the Ec on the definition of wastes. The Commission views wastes as a good and waste treatment as a service. That is, the free movement of wastes around Europe is defined in the same terms as the movement of services, washing machines, or skilled labour. Hence, restrictions upon the free movement of wastes are considered inconsistent with the goals of the $199^{2}$ programme. Because the harmonization

21 'Brussels takes a strong lead,' Financial Times (London), 6 March 1987.

22 'Die Wirtschaft wird vom Binnenmarkt profitieren,' Handelsblatt, 26 January 1989. 
of waste disposal laws will be difficult and time-consuming, it seems likely that waste tourism will grow after 1992. There is sentiment both within the Commission and in some memberstates that wastes should be dealt with at the facility closest to the site of their generation, ${ }^{23}$ but no Community-wide policy has yet been proposed by the Commission.

Clearly, then, the Ec's efforts in the area of waste management have been limited. This is in part a function of the late inclusion of environmental concerns in the EC treaties and in part of the difficulty the Commission experiences in forcing compliance with Ec directives. The Commission's definitions of waste and waste management are also indicative of its market first, environment second views. The overriding constraint upon EC policy regarding wastes is that the primary power still resides in the member-states, and there are significant differences of view among the members about the political salience of the issue.

AIR POLLUTION AND 1992

The (suppressed) assessment of the environmental impact of the 1992 programme put together by DG X I suggests that increased air pollution will be one of the major problems generated by the opening of markets in Europe. The report finds that air pollution from the two main sources, use of vehicles and generation of electricity, ${ }^{24}$ will grow after 1992 . Using the Commission's own models of the economic effects of the 1992 programme, ${ }^{25}$ the report finds that, even if existing environmental standards were fully implemented, levels of sulphur dioxide will rise by 8

23 G. Bennett et al, The Internal Market and Environmental Policy in the Federal Republic of Germany and the Netherlands (Brussels: Institute for European Environmental Policy, November 1989), 94 .

24 The report suggests that 60 per cent of all sulphur dioxide, 80 per cent of nitrogen oxides, 55 per cent of carbon dioxide, and $4^{\circ}$ per cent of non-methane hydrocarbons emissions come from these two sources. See Directorate General for Environment, Consumer Protection, and Nuclear Safety, The Environment and the Internal Market: Challenges and Opportunities, nd.

25 That is, those used to develop the projections in the Cecchini Report. See P. Cecchini, The European Challenge 1992: The Benefits of a Single Market (Brussels: The Commission 1988). 
to 9 per cent by 2010 and levels of nitrogen oxide by 12 to 14 per cent.

The implementation of the 1992 programme will lead to more air pollution from vehicles for several reasons. First, with the projected opening of borders, the movement of goods will be easier, and trade within the Ec will grow. Much of this increased trade will be carried by truck, adding to current vehicle-based pollution. Even if increased integration of the transportation sector might partly offset these increases in air pollution, ${ }^{26}$ the overall impact is likely to be negative. Additionally; the opening of hitherto closed transportation markets is likely to stimulate transportation by truck rather than by train. Rail has been losing out to road shipment for several years, and there is no Europewide effort to reverse this trend.

The second major source of air pollution is energy production. The effects of 1992 in the energy sector are mixed. On the one hand, a Europe-wide market in some energy sectors particularly oil refining - already exists, and $199^{2}$ is likely to have a minimal impact there. In other sectors, such as the market for electricity, significant national barriers continue to distort trade. ${ }^{27}$ The problem is not simply the desirability of national self-reliance in energy production despite the air pollution generated by oil- and coal-fired plants. The possibility of France marketing electricity generated by its nuclear power plants to Germany has raised concerns among anti-nuclear groups as

26 The transportation industry is one of the most heavily protected industries in Europe. In Germany, for example, foreign shippers are limited to a few thousand permits per year, leading to many instances in which trucks return empty from trips because they do not receive an additional permit to carry goods on the way back. Hence, a freeing of this market would allow carriers to be loaded most of the time, cutting back upon the number of unloaded trips - and the air pollution generated by these trips. Most estimates, though, find that the increased traffic resulting from the internal market will more than offset the increased efficiency arising from the elimination of the permit system. See The Environment and the Intermal Market.

27 Authors' interviews in Brussels, 9 November 1988; K. Matthies, 'Deregulierung des Energiemarktes?' in O.G. Mayer, H. Scharrer, H. Schmahl, eds, Der Europäische Binnenmarkl: Perspektiven und Probleme (Hamburg: Verlag Weltarchiv 1989), 175-94. 
well. ${ }^{28}$ While the transborder shipment of electricity is likely to affect only border regions initially, the likelihood is growing of long-term effects resulting from the movement of electricity generation from countries with high air pollution standards to those with lower standards.

The Ec initially made very little progress on the regulation of air pollution following the first directives to control air pollution approved by the Council in 1980 . Johnson and Corcelle attribute these delays to the oil crisis and the ensuing scarcity of low sulphur oils. They add that there was considerable opposition to controls over industrial air pollution from the larger members of the Ec, including Germany. ${ }^{29}$ Since 1980 , however, the effects of acid rain have become more widely known, and more attention is being paid to air pollution in Europe.

Regulation of air pollution from vehicles has focused upon two issues, the reduction of emissions through re-engineering, including the use of catalytic converters, and the elimination of lead in gasoline. The Danish veto of auto emissions standards proposed in 1985 (because they were not stringent enough) pushed members to tighten the controls. ${ }^{30}$ In June 1988, when the qualified majority voting rules of the SEA had taken effect, a coalition was found in the Council in favour of strict standards for all autos over 1.4 litres. Limits on emissions for diesel engines had been agreed upon shortly before. These standards were tightened in June of $19^{8} 9$ to include all cars and to require the use of catalytic converters. ${ }^{31}$ Eliminating lead in gasoline has proven more difficult. Current EC regulations call for the grad-

28 For analysis of such fears in Germany, see Bennett et al, The Internal Market and Environmental Policy in Germany and the Netherlands, 99.

29 Johnson and Corcelle, The Environmental Policy of the European Communities, 10910.

3o 'Nationale Interessen blockieren gemeinsame EG-Umweltpolitik,' Frankfurter Allgemeine Zeilung, 30 November $19^{8} 5$.

31 'EG-Umweltminister beschliessen niedrige Abgaswerte für Kleinwagen,' ibid, zo June 1988; 'Töpfer kämpfte vergeblich gegen die Umweltschutz-Bremser der EG,' Frankfurter Rundschau, 18 June 1988; 'A new revolution is set to check the bad habits of European industry, Guardian, 24 June 1989. 
ual elimination of lead in gasoline, but individual members may not impose their own (higher) standards on transborder shippers and must provide them with the same types of gasoline available in their home countries. ${ }^{32}$

Control of emissions from electricity generating plants has been slow. Initial Commission proposals were tendered in 1983 , but a compromise could be reached only five years later. This understanding allowed several members, including Italy, Great Britain, Spain, Portugal, Ireland, and Greece, extra time to meet the new standards.

Much as in the case of waste management, the initiative for stronger environmental standards regarding air pollution rests in the hands of member-governments. In contrast to the waste case, though, the high political saliency of air pollution problems has given the ec some additional leeway in pushing for Europewide solutions. That air pollution cannot be stopped at borders, as can solid wastes, heightens the need for pan-European remedies. However, the compromises reached tend to reflect the demands of the foot-draggers in the Ec.

CONCLUSIONS

This paper has analysed the role that environmental policy plays in the EC and its 1992 programme in order to shed light on the growing debate between scholars who emphasize the growing sovereignty of the EC and those who stress the continued independence of the nation-state. Various constraints upon the development of environmental policy were examined, and the development of Community policy in the areas of waste management and air pollution was briefly explored. It was found that there are two main constraints upon the development and implementation of environmentally sound policies for Europe. One is the focus within the Commission on completing the inter-

32 C. Hey and J. Jahns-Boehm, Ökologie und Freier Binnennarkt, a study prepared for the Öko-Institut Freiburg and the European Environmental Bureau (Freiburg: Schwartz auf Weiss 1989), 98-9. 
nal market at all costs, including if necessary environmental ones. The second is the continued dominance of national governments in the development of European policy in general.

It is clear that completion of the internal market is higher up on the Commission's political agenda than is protection of the environment. The Commission's president was unwilling to tolerate criticism - or what might in some circles be used as criticism - of the 1992 programme when the directorate general concerned explored the environmental impact of completing the internal market. Mr Delors's position is supported by European business, and, at least in part, by the European Trade Union Confederation. The inclusion of environmental concerns in the Single European Act was clearly not enough to ensure that a balance would be struck between market and environment. The Commission's definition of waste and waste management in market terms is an example of the implications of the emphasis on the internal market over other goals. While it can be argued that market and environment are not disparate goals, in practice it seems that they are treated by the major actors in European politics as if they are. This helps the nation-state maintain its competence in environmental issues.

The second constraint upon a European environmental policy is the continued dominance of nation-states in decision-making. Political power in the ec remains in the hands of its members. Even when agreements are reached at the European level, governments are often able to negotiate long adjustment periods, and there is some evidence that violations continue even after these adjustment periods have expired. Many of the directives passed by the Ec allow considerable variance among members in acceptable levels of pollution, and monitoring remains largely in the hands of member-governments. This is clearly the case in the area of air pollution.

The question remains: what would happen if the Commission were to focus more vigorously upon the environment? It seems unlikely that this would lead to any greater progress towards co-operative environmental policy. Unlike the case with 
the opening of markets, there is little shared perception of concern among EC members. While most can agree upon the need to address global environmental problems such as ozone depletion, it is more difficult to find common ground on more localized problems such as dumping at sea or waste tourism.

This analysis suggests several important implications for our understanding of regional integration. First, these data do not support the neo-functionalist emphasis upon spillover as the source of institutional change in the Ec. The process by which the Commission acquires more competence still runs first and foremost through national capitals. Further, these data suggest that national capitals retain much of their influence over EC policy, particularly when the Commission relies on directives rather than regulations to enact European policies. Clearly, the more controversial the issue, the more likely it is that the Commission will provide members with significant leeway on implementation, with the consequence that power continues to rest in national capitals. As a number of scholars have noted, harmonization in the $\mathrm{EC}_{\mathrm{C}}$ is more difficult that lowering barriers. The use of directives to lessen the conflict over harmonization, however, allows trade- and investment-distorting national policies to remain in place and defeats efforts to create a common market in Europe. The differences between negative integration (lowering of barriers) and positive integration (harmonization of policies) do become narrower over time. Finally, the EC remains first and foremost a business association. The expansion of EC sovereignty outside of narrowly defined market areas and into broader issues including environmental protection is problematic. The impetus for change in the Ec comes from élite groups such as business or from heads of state, and not from nationally based environmental groups. This reaffirms the importance of the nation-state and the continuing difficulty in developing Europe-wide views of environmental problems.

What this suggests is a European Community which is mostly a forum within which states can pursue their own independent foreign policies, in coalition with others when necessary or con- 
venient. Such a view of the Ec is at loggerheads with the initial formulations of integration theory as well as some of its more recent reformulations. This analysis suggests the need for caution in assessing the implications of the $199^{2}$ programme for the question of sovereignty. While 1992 will certainly bring about significant changes in Europe, substantial transfers of sovereignty from the nation-state to the $\mathrm{EC}$ and its institutions cannot be expected. 